\title{
The Competitiveness of the Textile Industry in Vietnam: An analysis to the Period of a Decade
}

\author{
Khac Dung Do \\ Graduate Academy of Social Sciences, Vietnam
}

\begin{abstract}
This paper analyzes the competitiveness of the textile and garment industry in Vietnam for the period 2010 to 2020 . The analysis is performed using two approaches applied on both quantitative and qualitative aspects the Generalized Double Diamond Model (GDDM), analyzed international competitiveness of Vietnam's G\&T industry and compared it with China and impact variables of international competitiveness to market share (MS), trade competitiveness (TC) and revealed comparative advantage (RCA) are tested against the estimated coefficients of these variables. The results from show that Vietnam was less competitive than China and it is necessary to increase investment in fixed assets of Vietnam's textile and garment industry, accelerate the rate of equipment upgrading, improve the level of industrialization, and at the same time increase the supply of spare parts. textile materials and lower the cost of raw materials prices, thereby reducing costs for textile enterprises.

Keywords: Competitiveness, Diamond model, Garment \& Textile, RCA index, Vietnam

*Corresponding author: Khac Dung Do; Email: dungdovina12@gmail.com

DOI: https://doi.org/10.37227/IJEKM-2021-05-947
\end{abstract}

\section{Introduction}

Garment and textile (G\&T) industry has been playing as a driving force for the socioeconomic development of Vietnam. With the international integration process and rising challenges from the global market, there is a need to examine international competitiveness of Vietnam's G\&T industry to find out what Vietnam should focus on to enhance its position in the global marketplace. Vietnam is becoming a progressively important garment exporting country. The textile and garment sector of Vietnam is one of the country's largest industries and a key contributor to the nation economic growth. In 2015, Vietnam's textile and garment exports increased 9.1 percent year over year to total approximately US $\$ 22.81$ billion, accounting for 15 percent of the country's gross domestic product (GDP) and 18 percent of its total exports (Chi, 2016). According to Le., H.T, 2017, Vietnam's textile and garment industry has been developing strongly and plays an increasingly important role in the growth of the national economy. Therefore, the business efficiency as well as the existence and development of textile and garment enterprises have 
great impact on the social-economic development of Vietnam. In 2017, Vietnam's textile and garment industry received US\$31 billion from exports and a year-on-year increase of over 10 percent. In 2019, the textile and garment industry reached an export turnover of more than US\$ 39 billion, which accounted for $16 \%$ of GDP. In the past five years, the textile industry has continuously grown at an average rate of 17 percent annually (General Statistics Office of Vietnam, 2020). Vietnam is the fourth largest exporter of textiles, garments, and clothing worldwide after China, the European Union and Bangladesh (Statista, 2020). As a result, garments and clothing have become the country's third largest export product (Statista, 2020).

However, fully trade liberalization has provoked a keen competition for lowincome countries, explicitly competition from other giant economies-India and China would expand its labor-intensive exports; additionally, competitions from other garment and textile exporting countries from South Asia-namely Bangladesh and Pakistan also erode Vietnam position since they could obtain lower labor cost and larger labor abundant (Nordoas, 2004). Therefore, the competitiveness of Vietnam's textile and garment industry is also greatly affected. This study aims to determine the competitiveness of Vietnamese garment exports. Two approaches applied both quantitatively and qualitatively, the RCA index and Porter's Diamond Model, were used to analyze and assess the competitiveness of Vietnam's garment exports from 2012-2020.

\section{Literature Review}

Notion of competitiveness could be found in the work of Adam Smith's Wealth of Nation, so called "absolute advantage"; and later, David Ricardo's comparative advantage theory in 1817 (Kilic, 2002). Remarkably, further extension of comparative advantage theoremHeckscher-Ohlin(H-O) theory of comparative advantage has dominated competitiveness study in the early half 21 stcentury (Debaere, 1998). However, base comparison of factor endowment and capability to produce at low cost to determine country's comparative advantage seems to be obsoleted; as more or less, county will use those factors abundant and technology to produce goods and service at lower cost in exporting to other countries. So comparative advantage of country shall be revealed in term of export performance instead, that's why Balassa (1965) have developed new measurement of country comparative advantages to determine a country's weak and strong sectors through export performance, called revealed comparative advantage (RCA) of Balassa Index.

Bender \& Li (2002) found that East Asian economies could obtain competitiveness only in textile, wearing apparel and leather sectors while Latin American economy could obtain substantial competitive advantages during the 1990s. Different technique of RCA usage by comparing different scenario analysis could be found in the work of Ahmad (2013) through comparing both regional giant economies of China, India and Bangladesh competitiveness over different period and scenario of the study as before trade liberalization (1980-1994) and in the post-trade liberalization (1995-2004) and in the post-quota abolition (2005-2011). Manchuria (2013) employed Revealed Comparative Advantage (RCA) in dynamic analysis and adding Spearman rank correlation (SRC) coefficient analysis to determine India and Bangladesh's clothes export 
competitiveness in the world trade through the period of 1995-2003 which revealed that Bangladesh has negative dynamic RCA and achieved lower correlation coefficient than India. Recent evidence from Shahzad (2015) who employed revealed comparative advantages (RCA) of Balassa's Index in his study found that Bangladesh obtains a strong comparative advantage for clothing sectors; Pakistan has more comparative advantage in the textile sector while India is far worst in both textile and clothing. Also, Cheng (2010) applied two research approaches to analyze the industrial competitiveness of garment industry of Guandong province in China (Cheng, 2010). For the quantitative aspect, the Revealed Comparative Advantage Index (RCA) was used to present the industrial competitiveness of the investigated industry. For the qualitative aspect, the discussion of the evaluated garment industrial competitiveness was done by using the Porter "Diamond Model". These methods have been shown to be effective and helpful approaches. The export potential of Indian textiles industry in a special period, named Post Multi Fiber Agreement, was revealed in the study of Chaudhary (Chaudhary, 2016). The Revealed Comparative Advantage (RCA) index was also used in this study to determine the development of India's textiles industry

Even though Vietnam's G\&T industry is a common topic for researchers in Vietnam, the previous literature on its international competitiveness is limited. The past studies examining international competitiveness of Vietnam's G\&T adopted three main approaches namely the value chain, strengths, weaknesses, opportunities, and threats (SWOT) and the Diamond Model of Michael Porter. Vitas (2006) used SWOT and value chain analysis to assess Vietnam's G\&T international competitiveness through a great deal of indicators, for example cost, production time, customs procedures, policies and supporting industries in comparison with some main competitors such as China, India, the US, Bangladesh and Thailand. A mixed picture was pointed out in the paper and eventually it was not clear of whether Vietnam's international competitiveness in G\&T industry was higher or lower compared to that of other competitors. Also using the value chain approach, Truong et al. (2010), Luong (2012) and Huong et al., (2016) argued that Vietnam's G\&T competitive was still low because of its participation in the lowest end of global G\&T value chain. Nguyen (2012) and Long (2018) using SWOT and the Diamond Model, and IPP and CIEM (2013) adopting the value chain and the Diamond Model drew out the same conclusions that Vietnam was at low competitiveness mainly because of its dependence on the outside raw material, weak supporting industries and low productivity. Asian Foundation and CIEM (2012) also found out that Vietnam's G\&T international competitiveness was modest and affected by tariff, customs, financial policies, labor, technology, materials input, market, and products quality. The previous studies recommended that in order to improve the international competitiveness of Vietnam's G\&T industry, Vietnam should increase the localization rate, develop Vietnam's brand name, and increase the added value to move up in the value chain. 


\section{Methods}

\section{Status of international competitiveness of Chinese textile and clothing industry *Market share}

Market share represents the ratio of a certain product's exports in a country or region to that of such product in the world's export. This indicator can directly reflect the competitiveness of the product and can objectively reflect a countries or region's share of the world market. The calculation formula is expressed as:

$$
M S=X a b / X w b
$$

In Formula (1),

Xab represents the export value of product $b$ of country $a$,

$\mathrm{Xwb}$ represents the world's export value of product $\mathrm{b}$.

This index is the most direct and simple indicator reflecting the level of an industry's international competitiveness, that is, the greater the value, the stronger the industry's international competitiveness is.

*Trade competitiveness

Trade competitiveness (TC) is calculated by dividing net exports to total trade. Net export, also known as the balance of trade, is the difference between the total amount of exports and total amount of imports. It generally reflects the status of a country's foreign trade balance; it is the main indicator reflecting the role of foreign trade in the national economy. Its formula is expressed as:

In Formula (2),

$$
T C i j=(X i j-M i j) /(X i j+M i j)
$$

TCij represents the trade competitiveness index of product $j$ of country $i$,

$\mathrm{Xij}$ and Mij represent the export and import volumes, respectively.

Trade competitiveness index ranges from 1 to 1 . When $0.8<=\mathrm{TC}<1$, it indicates that the product has an outstanding competitive advantage. Whrn $0.5<\mathrm{TC}<0.8$, the product has a higher competitive advantage. When $0<\mathrm{TC}<0.5$, the product has no obvious competitive advantage. The closer the index is to -1 , the more competitive the product is, the closer the indexx is to 1 , the stronger is the international competitiveness of the product. The closer the index is to 0 , the closer the level of competitiveness is to the average.

\section{*Revealed comparative advantage}

The methodology in measuring competitiveness of industry owes a great deal to Balassa (1965) on his revealed comparative advantage (RCA). RCA measures the relative advantage or disadvantage of a certain country in a certain class of goods or services. RCA equals to the proportion of the country's exports of a certain commodity divided by the proportion of world exports of such commodity. The formula is expressed as:

$$
R C A i j=(X i j / X i) /(X w j / X w)
$$

In Formula 3, RCAij represents the comparative advantage of product $j$ of country $i$, Xij represents the exports of products $j$ of country $i$,

$\mathrm{Xi}$ represents the total exports of country $\mathrm{i}$,

Xwj represents world exports of product $j$

Xw represents world total exports of all goods.

When RCA $>2.5$, product $\mathrm{j}$ has a strong export competitiveness; when RCA is between 1.25 and 2.5 , product $\mathrm{j}$ has a relatively strong export competitiveness. When RCA is between 
0.8 and 1.25 , product $\mathrm{j}$ has medium competitiveness, whereas when $\mathrm{RCA}<0.8$, product $\mathrm{j}$ has low competitiveness.

Table 1. Indicators of the Vietnam textile and clothing industry international competitiveness

\begin{tabular}{|l|l|l|l|l|l|l|l|l|l|}
\hline Year & 2012 & 2013 & 2014 & 2015 & 2016 & 2017 & 2018 & 2019 & 2020 \\
\hline Market share & 0.25 & 0.27 & 0.28 & 0.29 & 0.29 & 0.31 & 0.32 & 0.34 & 0.35 \\
\hline $\begin{array}{l}\text { Trade } \\
\text { competitiveness }\end{array}$ & 0.69 & 0.73 & 0.76 & 0.76 & 0.76 & 0.74 & 0.73 & 0.74 & 0.79 \\
\hline $\begin{array}{l}\text { Revealed } \\
\text { comparative } \\
\text { advantage }\end{array}$ & 3.04 & 3.02 & 3.09 & 3.09 & 2.96 & 2.96 & 3.04 & 2.92 & 2.51 \\
\hline
\end{tabular}

(Source: author's calculate)

As it can be seen from Table 1, the market share from 2012 to 2020 keeps on increasing. This objectively proves that Vietnam textile and clothing industry is continuously enhancing its international competitiveness; the trade competitiveness also keeps on increasing. Also, it has been greater than 0.5 and less than 0.8 ; this indicates that Vietnam textile and clothing industry still has a relatively high international competitive advantage. Though the revealed comparative advantage shows a downward trend from 2018 to 2020 (3.04 to 2.51, respectively), all the figures are greater than 2.5, meaning that Vietnam textile and clothing industry has strong export competitiveness.

\section{Influencing factors of international competitiveness of Chinese textile and clothing industry}

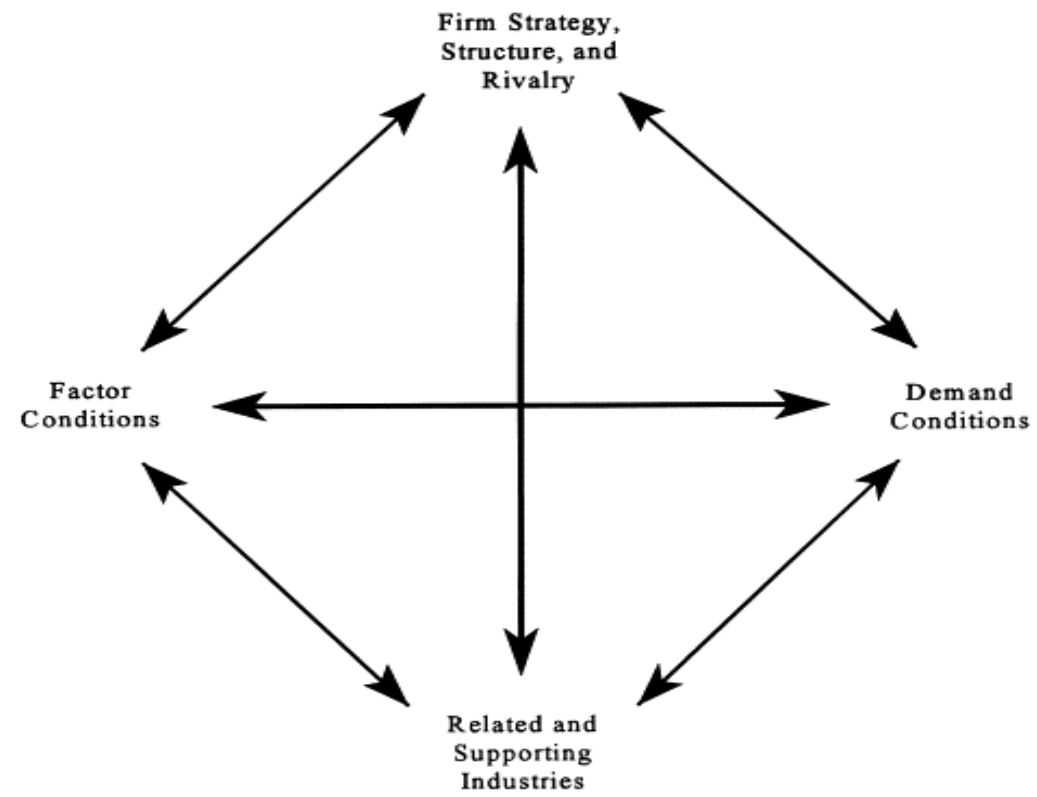

Figure 1. The Diamond Model

Source: Moon et al. (1998) 
Among the models that are adopted to explain nation or industry competitiveness, the widely used one is Michael Porter's Diamond Model introduced firstly in Porter (1990). According to this model, four main attributes that underlie conditions or platform for determination of the national competitive advantage are "Factor conditions", "Demand conditions", "Related and Supporting Industries", and "Firm Strategy, Structure and Rivalry". Porter (1990) also proposed government policies and chance as exogenous shocks, which supported the whole system of national competitiveness with four abovementioned attributes.

To assess the international competitiveness of Vietnam's G\&T industry, it is necessary to have a methodology that quantifies Vietnam's competitiveness and allows comparison of this level of competition with that of another country standard country. Therefore, GDDM was chosen because this model fulfils these two requirements. The model is also proven to be suitable for an open and developing country like Vietnam.

The comparison country chosen in this study was China, which is not only Vietnam's neighboring country sharing the similar cultures and traditions, but also the top G\&T exporter in the world. Domestically, the Vietnamese G\&T industry competes with China's in providing G\&T products to Vietnam's citizens. Internationally, the position that China's G\&T industry holds now is the one that Vietnam's G\&T industry heads for. Moreover, both China and Vietnam are among top G\&T exporters in the international marketplace. Comparing the competitiveness of Vietnam's G\&T industry to that of China is necessary for Vietnam to know where it is now in the race with China. Therefore, although China is the second biggest country in the world in terms of GDP, the comparison of two nations at G\&T industry level is acceptable if cautious analysis is taken when examining proxies that are not at industry level like total population and total GDP.

The key issue is the choice of proxies capturing four attributes that are assessed in the GDDM. The GDDM is developed from the original Diamond Model of Porter, which consists of four groups of attributes namely Factor conditions, Demand conditions, Related and Supporting industries, and Firm Strategy, Structure and Rivalry. In fact, the model has generated over 100 proxies that are used to capture international competitiveness. However, like other previous studies by Rugman and Verbeke (1993), Sardy and Fetscherin (2009), Balcarová (2010), Williams and Morgan (2010), and Son and Kenji (2013), this paper does not cover all proxies but chooses certain proxies which best capture international competitiveness of studied industry. Totally, 27 proxies that describe four attributes, taking into consideration G\&T industry-related features, were selected to act as determinants of the model (Table 2).

Table 2. Variables and proxies of GDDM for Vietnam's G\&T industry in comparison with China's

\begin{tabular}{|l|l|l|}
\hline Attributes & \multicolumn{1}{|c|}{ Variables } & \multicolumn{1}{c|}{ Proxies } \\
\hline \multirow{4}{*}{$\begin{array}{l}\text { Factor } \\
\text { Conditions }\end{array}$} & Domestic & Wage of worker in G\&T industry (USD/h) \\
\cline { 2 - 3 } & & $\begin{array}{l}\text { Number of workers and laborers in G\&T } \\
\text { industry (million people) }\end{array}$ \\
\cline { 3 - 3 } & Basic factors & $\begin{array}{l}\text { Labour productivity in G\&T industry } \\
\text { (shirts/worker/day) }\end{array}$ \\
\cline { 2 - 3 } & Advanced factors & R\&D expenditure (\% of GDP) \\
\hline
\end{tabular}

International Journal of Education and Knowledge Management (IJEKM) 


\begin{tabular}{|c|c|c|}
\hline & \multicolumn{2}{|l|}{ International } \\
\hline & \multirow[b]{2}{*}{ Advanced factors } & $\begin{array}{l}\text { Manufacturing inward FDI flows (billion } \\
\text { USD) }\end{array}$ \\
\hline & & $\begin{array}{l}\text { Manufacturing outward FDI flows (billion } \\
\text { USD) }\end{array}$ \\
\hline \multirow{9}{*}{$\begin{array}{l}\text { Demand } \\
\text { Conditions }\end{array}$} & \multicolumn{2}{|l|}{ Domestic } \\
\hline & \multirow[b]{3}{*}{ Size } & Total population (million people) \\
\hline & & GDP (billion USD) \\
\hline & & Employment rate $(\%)$ \\
\hline & \multirow[b]{3}{*}{ Sophistication } & GDP per capita (USD) \\
\hline & & $\begin{array}{l}\text { Household rate of expenditure on G\&T out } \\
\text { of gross income }(\%)\end{array}$ \\
\hline & & Educational index \\
\hline & International & $\begin{array}{l}\text { Total export value of G\&T industry (billion } \\
\text { USD) }\end{array}$ \\
\hline & Size & $\begin{array}{l}\begin{array}{l}\text { Average export growth rate of } \mathrm{G} \& \mathrm{~T} \\
\text { industry }(\%)\end{array} \\
\end{array}$ \\
\hline \multirow{11}{*}{$\begin{array}{l}\text { Related and } \\
\text { Supporting } \\
\text { Industries }\end{array}$} & \multicolumn{2}{|l|}{ Domestic } \\
\hline & \multirow[b]{2}{*}{ Supporting Industries } & Cotton output $(1000 \mathrm{t})$ \\
\hline & & Yarn output (million tons) \\
\hline & \multirow{3}{*}{$\begin{array}{l}\text { Supporting } \\
\text { infrastructures }\end{array}$} & Rail lines (total route $-\mathrm{km}$ ) \\
\hline & & Roads, paved ( $\%$ of total roads) \\
\hline & & ICT index \\
\hline & \multicolumn{2}{|l|}{ International } \\
\hline & \multirow[b]{2}{*}{ Supporting industries } & Cotton exports $(1000 \mathrm{t})$ \\
\hline & & Yarn and fabric exports (billion USD) \\
\hline & \multirow[b]{2}{*}{$\begin{array}{l}\text { Supporting } \\
\text { infrastructures }\end{array}$} & $\begin{array}{l}\text { Container port traffics (TEU: } 20 \text { foot } \\
\text { equivalent unit) }\end{array}$ \\
\hline & & $\begin{array}{l}\text { Air transport (registered carrier departures } \\
\text { worldwide) }\end{array}$ \\
\hline \multirow{6}{*}{$\begin{array}{l}\text { Firm Strategy, } \\
\text { Structure and } \\
\text { Rivalry }\end{array}$} & \multicolumn{2}{|l|}{ Domestic } \\
\hline & Rivalry & Intensity of local competition \\
\hline & Business context & World Bank DTF points \\
\hline & \multicolumn{2}{|l|}{ International } \\
\hline & Rivalry & $\begin{array}{l}\text { Market share of the country in G\&T global } \\
\text { market (\%) }\end{array}$ \\
\hline & Business context & $\begin{array}{l}\text { Average import tariff rate faced by G\&T } \\
\text { industry }(\%)\end{array}$ \\
\hline
\end{tabular}

Source: Developed by the authors based on Rugman and Verbeke (1993), Sardy and Fetscherin (2009), Balcarová (2010), Williams and Morgan (2010), Son and Kenji (2013) 
After data for the above-mentioned proxies were collected, they were then translated into scores to quantify international competitiveness of G\&T industry in Vietnam and the benchmark nation, China. The method of score translation used in this study was similar to the one used in Rugman and Verbeke (1993) and Sardy and Fetscherin (2009). Firstly, the value of 100 was set for a benchmark country in all proxies, and based on that, the value of each proxy in another country would be calculated accordingly. In this paper, the value of 100 was set for all proxies of China, the country of comparison and the competitiveness index of Vietnam's G\&T industry was then calculated accordingly. If a proxy where the higher value indicated more competitiveness, data of China were taken as the base or denominator in calculations. For instance, in the case of labor productivity in G\&T industry, a Vietnam's G\&T worker can produce seven shirts/day while that number of Chinese worker is 16 (Table 3 ). In contrast, if a proxy where the higher value indicated less competitiveness, data of China were be taken as the numerator. For instance, wage of a worker in G\&T industry of Vietnam is 2.99 compared to 6.5 of China (Table 3). Then, the competitiveness index of Vietnam for this proxy is $217.39 \%(6.5 / 2.99)$. Secondly, for each country, the index values of Domestic Diamond and International Diamond were calculated by using the simple average of all selected proxies and variables because they were considered equally important in determining international competitiveness. Thirdly, the global indexes were calculated by taking the simple average of the Domestic and International indexes, representing international competitiveness of Vietnam G\&T industry.

Table 3. Descriptive data for GDDM of Vietnam and China's G\&T industry

\begin{tabular}{|c|c|c|c|c|}
\hline Attributes & Variables & Proxies & Vietnam & China \\
\hline \multirow{8}{*}{ Factor Conditions } & \multicolumn{2}{|l|}{ Domestic } & & \\
\hline & \multirow[b]{3}{*}{ Basic factors } & $\begin{array}{l}\text { Wage of worker in G\&T industry } \\
\text { (USD/h) (2020) }\end{array}$ & 2.99 & 6.5 \\
\hline & & $\begin{array}{l}\text { Number of workers and laborers in } \\
\text { G\&T industry (million people) } \\
(2020)\end{array}$ & 2.7 & 25 \\
\hline & & $\begin{array}{ll}\text { Labor productivity in G\&T } \\
\text { industry (shirts/worker/day) } \\
(2019) \\
\end{array}$ & 7 & 16 \\
\hline & Advanced factors & $\begin{array}{l}\text { R\&D expenditure (\% of } \% \text { GDP) } \\
(2015)\end{array}$ & 1.48 & 2.08 \\
\hline & \multicolumn{2}{|l|}{ International } & & \\
\hline & \multirow[b]{2}{*}{ Advanced factors } & $\begin{array}{l}\begin{array}{l}\text { Manufacturing inward FDI flows } \\
\text { (billion USD) (2015) }\end{array} \\
\end{array}$ & 17.14 & 455.54 \\
\hline & & $\begin{array}{l}\text { Manufacturing outward FDI flows } \\
\text { (billion USD) (2015) }\end{array}$ & 1.96 & 71.97 \\
\hline \multirow{8}{*}{$\begin{array}{l}\text { Demand } \\
\text { Conditions }\end{array}$} & \multicolumn{2}{|l|}{ Domestic } & & \\
\hline & \multirow[b]{3}{*}{ Size } & $\begin{array}{l}\text { Total population (million people) } \\
(2020)\end{array}$ & 97.58 & 1441.7 \\
\hline & & GDP (billion USD) (2020) & 425.3 & $15,380.2$ \\
\hline & & Employment rate $(\%)(2020)$ & 75.9 & 63.5 \\
\hline & \multirow[b]{3}{*}{ Sophistication } & GDP per capita (USD) (2020) & 2123.46 & 10673.1 \\
\hline & & $\begin{array}{l}\text { Household rate of expenditure on } \\
\text { G\&T out of gross income }(\%) \\
(2020)\end{array}$ & 4.21 & 7.96 \\
\hline & & Educational index (2020) & 0.704 & 0.761 \\
\hline & International & $\begin{array}{l}\text { Total export value of G\&T } \\
\text { industry (billion USD) }(2020)\end{array}$ & 29.81 & 291.22 \\
\hline
\end{tabular}




\begin{tabular}{|c|c|c|c|c|}
\hline & Size & $\begin{array}{l}\text { Average export growth rate of } \\
\text { G\&T industry }(\%)(2012-2020)\end{array}$ & 11.8 & 9.6 \\
\hline \multirow{11}{*}{$\begin{array}{l}\text { Related } \\
\text { Supporting } \\
\text { Industries }\end{array}$} & \multicolumn{2}{|l|}{ Domestic } & & \\
\hline & \multirow{2}{*}{$\begin{array}{l}\text { Supporting } \\
\text { Industries }\end{array}$} & Cotton output (1000 t) & 1.36 & 6532 \\
\hline & & Yarn output (million tons) & 0.72 & 32 \\
\hline & \multirow{3}{*}{$\begin{array}{l}\text { Supporting } \\
\text { infrastructures }\end{array}$} & Rail lines (total route- $-\mathrm{km}$ ) & 2347 & 66,298 \\
\hline & & Roads, paved ( $\%$ of total roads) & 47.6 & 60.9 \\
\hline & & ICT index & 4.09 & 4.64 \\
\hline & \multicolumn{2}{|l|}{ International } & & \\
\hline & \multirow[b]{2}{*}{$\begin{array}{l}\text { Supporting } \\
\text { industries }\end{array}$} & Cotton exports $(1000 t)$ & 0.00 & 16,000 \\
\hline & & $\begin{array}{l}\text { Yarn and fabric exports (billion } \\
\text { USD) }(2020)\end{array}$ & 3.737 & 106.90 \\
\hline & \multirow[b]{2}{*}{$\begin{array}{l}\text { Supporting } \\
\text { infrastructures }\end{array}$} & $\begin{array}{l}\text { Container port traffics (TEU: } 20 \text { - } \\
\text { foot equivalent unit) }\end{array}$ & $8,121,019$ & $170,080,330$ \\
\hline & & $\begin{array}{l}\text { Air transport (registered carrier } \\
\text { departures worldwide) }\end{array}$ & 144,630 & $3,356,756$ \\
\hline \multirow{6}{*}{$\begin{array}{l}\text { Firm Strategy, } \\
\text { Structure and } \\
\text { Rivalry }\end{array}$} & \multicolumn{2}{|l|}{ Domestic } & & \\
\hline & Rivalry & Intensity of local competition & 5.10 & 5.40 \\
\hline & Business context & World Bank DTF points & 64.42 & 62.58 \\
\hline & \multicolumn{2}{|l|}{ International } & & \\
\hline & Rivalry & $\begin{array}{l}\text { Market share of the country in } \\
\text { G\&T global market }(\%)\end{array}$ & 3.16 & 34.69 \\
\hline & Business context & $\begin{array}{l}\text { Average import tariff rate faced by } \\
\text { G\&T industry }(\%)\end{array}$ & 12.4 & 12.8 \\
\hline
\end{tabular}

Source: Synthesized and Calculated By Authors

\section{Results And Discussion}

From descriptive data for Vietnam and China's G\&T industries shown in Table 2, the paper calculated and analyzed competitiveness indexes of two countries. Results of the Domestic Diamond, International Diamond are presented bellowed.

\section{Domestic Diamond}

Except for Factor Conditions, Vietnam's G\&T industry was less competitive than China's in all domestic determinants (Table 2). The reason behind the higher measurement of Vietnam's factor conditions was the abundant source of unskilled labor with low costs. Vietnam in 2020 was the 15 th most populous country in the world and had a golden population structure with the number of working people being twice as much as the number of dependent people (CIA 2020). However, more than 80 $\%$ of labors in Vietnam were untrained (General Statistics Office 2020) and therefore were low paid. According to Werner International, the average wages for labors in Vietnam's G\&T industry in 2020 was only $2.99 \mathrm{USD} / \mathrm{h}$, the lowest among Southeast Asian nations and 2.2 times lower than that in China (Table 2). In addition, the fee for labor training was also low in Vietnam since most of unskilled labors in Vietnam's 
G\&T industry learnt how to work by doing themselves and receiving advice from more experienced workers. G\&T is a labor-intensive industry and thus the labor cost has a substantial share in the total cost (IPP and CIEM 2020), leading to big cost competitiveness for Vietnam's G\&T industry. This cost competitiveness to some extent compensated for Vietnam's weaknesses in productivity (Yen, 2012), the number of workers in G\&T industry (Bui, 2014; Kane, 2014; Cao and Niu, 2017) and the amount of R\&D investment compared to China. As the result, Vietnam surpassed China in Factor Conditions.

\section{International Diamond}

Vietnam showed better Demand Conditions than China in the international context because G\&T exports of Vietnam witnessed a high growth rate of more than $11.8 \%$ compared to only $9.6 \%$ of China in the period 2012-2020 (Table 2). There were two reasons for this miraculous rate. Firstly, the world economy recovered from the global crisis, leading to higher income and demand for goods and services all over the world. Secondly, Vietnam took well advantage of the EU-Vietnam Partnership and Cooperation Agreement (PCA) signed in 2012 and the EU's debt crisis, when the EU's demand for luxury goods decreased but for necessity goods like food and clothes increased. In addition, in this difficult time, the EU's consumers had a tendency to come back to products with reasonable prices and quality like those made by Vietnam (Vietnam Trade Promotion Agency 2013). In 2012-2016, when the Eurozone was deep in the debt crisis, the growth rate of Vietnam's G\&T exports to the EU reached more than $8.4 \%$ while this rate for China was $-2.3 \%$. Besides, Vietnam-Japan Economic Partnership Agreement, the newly signed Vietnam-Korean FTA and the forthcoming European Union and Vietnam FTA (EVFTA) are also motives for Vietnam to expand exporting G\&T products to these key partners. Therefore, though the absolute exports of Vietnam's G\&T industry were still low compared to China's, the remarkable growth rates made Vietnam more competitive than China in international Demand Conditions attribute.

\section{Conclusions}

On the basis of the Diamond Model, this paper examines the impact of raw materials, demand, related industries, business strategies and policies, and other relevant factors on the international competitiveness of China's textile industry by using data from 2012 to 2020. The results of this study show that out of the 27 selected agents, Vietnam only outperforms China in 4 items of billion employment rate, average G\&T export growth, DTF score and average import tax rate. As a result, the domestic Diamond sector of Vietnam's G\&T industry has lower measures than China's in all attributes, except Factor Conditioning. With International Diamond, Vietnam is only more competitive in terms of Demand Conditions. Overall, Global Diamond shows that Vietnam's G\&T industry is much less internationally competitive than China's in all four characteristics.

The biggest gap between Vietnam and China's international competitiveness in G\&T industry was realized in Related and Supporting industries. The low competitiveness of Vietnam originated from consistent problems of inadequate downstream and upstream industries including the insufficiency of cotton and yarn production; foreign-reliant G\&T marketing and distribution; and weak transportation system for traded goods. Besides, the shortage of G\&T cluster in Vietnam deteriorated the competitiveness of this industry internationally.

International Journal of Education and Knowledge Management (IJEKM) 
The second biggest gap was reported in Factor Conditions, in which Vietnam's lower competitiveness came from the low labor productivity, limited R\&D expenditure and especially far lowers inward and outward FDI in the manufacturing sector of Vietnam. Vietnam's G\&T industry development has so far relied heavily on low-cost labor that was not sustainable for future growth.

The third biggest gap between Vietnam and China in Global Diamond was Firm Strategy, Structures and Rivalry. Vietnam was better than China in business context with higher DTP point and lower average import tariff because of the dynamic international integration, but China exceeded Vietnam in terms of intensity of local competition and global market share.

With all the above results, to improve the international competitiveness of the science and technology industry, Vietnam needs to improve all four attributes above, which is extremely important. However, this article argues that Vietnam should first place a high priority on promoting related and supporting industries. Developing cotton production, diversifying, and improving yarn quality, supporting businesses to build their own distribution channels, setting up G\&T clusters and upgrading overseas freight transport are among the measures to improve the quality of cotton. urgent to strengthen G\&T related and supporting industries in Vietnam. This is followed by a mission to improve Factor Condition by investing more in training G\&T workers to improve productivity and training skilled workers to improve R\&D in the industry. Finally, Vietnam should strive to maintain its current strength over China in terms of G\&T export growth and favorable business landscape by leveraging existing FTAs as well as the promising EVFTA and TPP appointment.

\section{Limitation \& Future research}

Finally, this article chooses China, a developing country but much larger than Vietnam in terms of GDP, population and area, as the benchmark country to compare with Vietnam. To provide a multi-dimensional analysis of G\&T Vietnam's international competitiveness, more accurately determine Vietnam's G\&T international competitiveness gap with key competitors and, more importantly, recommend As a progressive measure for Vietnam to improve its international competitiveness, future research may consider some other comparable countries of similar size such as Cambodia, Bangladesh, and Thailand.

\section{Research Limitations and Directions for Future Study}

The paper is based on secondary study while primary research including surveys can be conducted among managers in future to understand the competitiveness of the textile industry in Vietnam from the managerial perspectives. Moreover, the study only included the textile industry of Vietnam therefore the results should be used cautiously in the context of other countries. However, in the future, researchers can conduct comparative studies to understand more about the competitiveness of the textile industry of different countries where this industry plays a vital role. Furthermore, the study has included data from 2010 to 2020 , therefore, in future some more similar studies are recommended to keep the literature updated relating to competitiveness of the textile industry. 


\section{References}

Ahmad, N. (2013). Changing Revealed Comparative Advantage of Textile and Clothing Sector of Pakistan: Pre and Post Quota Analysis. Pakistan Journal of Commerce and Social Sciences, 7(3), 520-544.

Asian Foundation, CIEM (2012) The competitiveness of export enterprises in three sectors: garment and textiles, fisheries, and electronics in Vietnam. The Asian Foundation, Center Institute for Economic Management, Hanoi

Balassa, B. (1965). Trade liberalisation and "revealed" comparative advantage. The Manchester School, 33(2), 99-123.

Balcarová P (2010) The generalized double diamond model-application for Czech Republic and Slovakia. In: 2nd international $\mathrm{PhD}$ student conference in new economic challenges, University of Masaryk University, Brno, 20-21.

Bui VT (2014) Garment and textiles report. FPT Securities, Hanoi

Bender, S., \& Li, K. W. (2002). The changing trade and revealed comparative advantages of Asian and Latin American manufacture exports. Yale Economic Growth Center Discussion Paper, (843)

Chi, D. Q. 2016. Vietnam country study Labor Standards in the Garment Supply Chain. Strategic Partnership for Garment Supply Chain Transformation. CNV International - Research Center for Employment Relations.

Cao, K.X. and Niu, J.S. (2017), “Analysis on the international competitiveness of beijing's cultural creative industries", American Journal of Industrial and Business Management, 7(3), pp. 143-159.

Cheng, W. 2010. The Competitiveness of Export-Oriented Garment Industry in Guangdong (China) in the Post-Crisis Era MBA, Lund university.

Chaudhary, A. 2016. Revealed Comparative Advantage Index: An Analysis of Export Potential of Indian Textiles Industry in the Post MFA Period. 6, 344-351.

Debaere, P. (1998). "Endowments Do Matter" Relative Factor Abundance and Trade. Research Seminar in International Economics Discussion Paper No.

General Statistics Office of Vietnam, 2020. https://www.gso.gov.vn/ (Accessed 08/10/2021)

Huong, T. V., \& Lam, C. P. (2016). A dynamic approach toassess international competitiveness of Vietnam's garment and textile industry. Springer Plus, 5, 203. doi: 10.1186/s40064-016-1912-3

Kane G (2014) Facts on China's garment industry. Clean Clothes Campaign, Amsterdam

Le., H. T (2017), Report on textile and garment industry, FPT Securities.

Luong TL (2012) The global garment and textiles value chain and participation of Vietnam's garment and textiles industry. Dissertation, University of Economcis and Business, Vietnam National University - Hanoi.

Long, T. T. 2018. Solutions to improve the export performance of Vietnam textile and garment enterprises. Vietnam Trade and Industry Review, 109-114.

Nguyen BV (2012) The competitiveness of Vietnam's garment and textiles exports to the EU in the context of WTO integration. Dissertation, University of Economics and Business, Vietnam National University - Hanoi.

Nordås, H. K. (2004). The global textile and clothing industry post the agreement on textiles and clothing. World, 7(1,000).

Moon HC, Rugman AM, Verbeke A (1998) A generalized double diamond approach to the global competitiveness of Korea and Singapore. Int Bus Rev 7(2):135-150 
Kilic, R. (2002). Absolute and Comparative Advantage: Ricardian Model. Michigan: Marshall Hall.

Shahzad, K. (2015). An RCA Analysis of Textiles and Clothing in Pakistan, India, and Bangladesh. The Lahore Journal of Economics, 20(1), 157-168.

Sardy M, Fetscherin M (2009) A double diamond comparison of the automotive industry of China, India, and South Korea. Compet Forum 7(1):6-16

Son MY, Kenji Y (2013) A comparative analysis on the competitiveness of Korean and Japanese fashion industry by applying Generalized Double Diamond Model. Asia Mark J 15(1):57-81

Truong HT, Nguyen TBT, Nguyen TL (2010) The value chain approach to industrial upgrading of Vietnam textile industry. J Sci Technol 2(37):158-168

Porter ME (1990) The competitive advantage of nations. Free Press, New York.

Rugman AM, Verbeke A (1993) Foreign subsidiaries and multinational strategic management: an extension and correction of Porter's single diamond framework. Manag Int Rev 33:71-84.

Vitas (2006) Vietnam's garment and textiles export strategy 2006-2010. Vietnam Textile and Apparel Association, Hanoi

Vietnam Trade Promotion Agency (2013) Export promotion report: 2012-2013 - trade promotion at local level Hanoi. Vietnam Trade Promotion Agency, Hanoi.

Yen T (2012) For the sustainable development of garment and textiles industry. J Ind 1:4041

Williams DA, Morgan B (2010) Benchmarking for international competitiveness: lessons for public policy. In: Proceedings of the 7th quest for global competitive conference, Puerto Rico. 